\title{
A Step up DC-DC Converter with Coupled Inductor for Renewable Energy Applications using MPPT
}

\author{
Parvathi Mohan ${ }^{1}$, Sreeja $\mathbf{E} \mathbf{A}^{2}$ \\ ${ }^{1}$ PG Student [Power Electronics \& Power System], Dept. of EEE, Federal Institute of Science \& Technology, Angamali, Kerala, India \\ ${ }^{2}$ Assistant Professor, Dept. of EEE, Federal Institute of Science \& Technology,, Angamali, Kerala, India
}

\begin{abstract}
In this paper, an isolated high step up dc-dc converter is included. In the past few decades, power electronic converters are exploited for industrial demands and they play a major role in high power equipment's for different applications. Use of power electronic converters is ever increasing in the processing of electrical energy in industrial applications such as uninterrupted power supplies, distributed photovoltaic generation systems, fuel cell energy conversion systems and other AC utility mains applications. Boost converters are widely used in the low to high dc-dc applications. In the recent years, significant efforts have been made on improving the performance of high power boost converters. In this project a isolated high step-up dc-dc converter with low voltage stress is presented. The proposed converter achieves extremely large voltage conversion ratio with appropriate duty cycle and reduction of voltage stress on the power devices. The topology utilizes coupled inductor. The leakage inductance energy can efficiently be discharged. Since the device stresses are low in this topology, low voltage MOSFETs with small $R_{D S}($ on) values can be selected to reduce the conduction loss. The Perturb and Observe algorithm was implemented for tracking the maximum power from the PV panel. These features improve the converter efficiency. When compared to other topologies the proposed converter contain only one switch which simplify the circuit configuration and improve the system reliability. All these factors improve the circuit performance in the high step-up applications
\end{abstract}

Keywords: coupled inductor,leakage inductance, voltage stress,mppt,isolated converter

\section{Introduction}

Over the years the portable electronics industry progressed widely. A lot requirement evolved such as increased battery life, small and cheap systems, coloured displays and a demand for increased talk-time in mobile phones. The increasing demand from power systems has placed power consumption at a peak. To keep up with these demands an engineer has worked towards developing efficient conversion techniques and also has resulted in the growth of an interdisciplinary field of power electronics.

A few applications of DC-DC converters are 5V DC on a personal computer motherboard must be stepped down to $2.5 \mathrm{~V}, 2 \mathrm{~V}$ or less for one of the latest CPU chips. Where, $2 \mathrm{~V}$ from a single cell must be stepped up to $5 \mathrm{~V}$ or $\mathrm{V}$ more, in electronic circuitry operation. Also in LED TV we need $12 \mathrm{~V}$ output voltage. So, we introduce DC-DC converter to step up or step down the voltage to the system. In all of these applications, we want to change the DC energy from one voltage level to another, while wasting of energy as little as possible in the process. In other words, we want to perform the conversion effectively with the highest possible efficiency. DC-DC Converters are in hit list because unlike AC, DC can't simply be stepped up or down using a transformer. DC-DC converter is the DC equivalent of a transformer in many ways. They are essentially just change the input energy into a different level. So, whatever the output voltage level, the output power all comes from the input. The fact that some are needful used up by the converter circuitry and components, in doing their work efficiently.

Nowadays, the renewable-energy grid-connected systems with photovoltaic (pv) and fuel cells call for high step-up and large-current $\mathrm{dc} / \mathrm{dc}$ topologies because the low voltage generated by the PV and fuel cells should be boosted to a relatively high dc bus voltage for the grid-connected generation systems. For example, in order to deliver the energy to a single-phase $220-\mathrm{V}$ utility grid, a $380-\mathrm{V}$ dc bus voltage is required with a full-bridge in-verter. Unfortunately, the output voltage of most fuel cell stacks or the individual PV cells is lower than $40 \mathrm{~V}$ due to the safety and reliability issues in the household applications. Large voltage conversion ratio with over ten times of voltage gain is necessary for the front-end dc/dc converters. As a result, nonisolated high-step-up converters are desirable to reduce the system cost and improve the power density by removing the isolated voltage or current sensors and additional auxiliary power supply in the isolated conversion systems.

The proposed converter achieves extremely large voltage conversion ratio with appropriate duty cycle and reduction of voltage stress on the power devices. The topology utilizes coupled inductor. The leakage inductance energy can efficiently be discharged. Since the device stresses are low in this topology, low voltage MOSFETs with small $\mathrm{R}_{\mathrm{DS}}$ (on) values can be selected to reduce the conduction loss. These features improve the converter efficiency. When compared to other topologies the proposed converter contain only one switch which simplify the circuit configuration and improve the system reliability. All these factors improve the circuit performance in the high step-up applications

\section{Literature Survey}

High step-up converters are widely used in industry, such as in battery charging, uninterruptible power supply (UPS) systems, and solar cell energy generating devices. Such converters boost low DC input voltages to high DC output

\section{Volume 4 Issue 11, November 2015}




\section{International Journal of Science and Research (IJSR) \\ ISSN (Online): 2319-7064}

Index Copernicus Value (2013): 6.14 | Impact Factor (2014): 5.611

voltages. For the UPS or solar cell system, relatively high step-up converters are needed, which are used to transfer the $\mathrm{DC}$ voltage to the AC output voltage. For many applications, such as battery powering systems, uninterruptible power supplies, solar cell powering systems, step-up converters are needed. The term Gain in electronics can be defined as the ability of a circuit to increase the power or amplitude of a signal from its input value. High voltage conversion converters are used for the voltage gain enhancement which is required in many applications. These converters increase the output voltages to a higher level from a lower input voltage level according to the requirement of load.

For improving the voltage gain, we can adopt different methods. The traditional methods are to use the converters like boost converter, buck-boost converter. But the voltage gains of these converters are not so high. Up to now many kinds of voltage boosting are available. The other techniques for voltage boosting are use of several inductors connected in series which are magnetized and then pumping the stored energy into the output, by the use of coupled inductors, Voltage super position based on switching capacitors, use of auxiliary transformers, use of multiplier cells, use of voltage lift circuits.

Nowadays, dc-dc converters with high voltage gain are widely used in single-phase grid-connected alternative energy sources employing fuel cells or photovoltaic (PV) panels particularly, the PV energy is considered as one of the most useful alternative energy sources because it is clean, unlimited, and cheap. However, the output voltage of the PV panels is low. Generally, the maximum power point (MPP) voltage is in a range of 20-40 V depending on power capacity of the PV panel. The PV panels could be connected in series to increase the input voltage of the converter. But, this decreases the MPP efficiency in case of any shading.[1]

In single-phase grid-connected ac module structure, it consists of a high step-up dc-dc converter in the first stage. A high voltage ratio converter is required to obtain high output voltage from low input voltage. However, such a converter has some drawbacks such as large input current and high voltage switching. This especially increases conduction losses when higher voltage rating devices are used. Isolated and nonisolated converters can be used to boost low input voltages. But, these converters have some drawbacks. In practical applications, voltage gains of nonisolated converters such as the conventional boost and buck boost are limited even at high duty cycles due to the losses on the parasitic components such as resistance of the inductor and equivalent series resistance (ESR) of the capacitor. Also, voltages on the switches in these topologies are at high levels. Besides, high duty cycle ratios can cause a serious reverse recovery problem on diodes [2]

Fly back and forward type isolated converters can achieve high voltage gains by adjusting the turn ratio of the transformer. However, the energy stored in the leakage inductance of the transformer causes high voltage stresses on the power devices in these converters. For this reason, various snubber circuits such as resistor-capacitor diode (RCD) [3], active [4], [5], [6], and voltage-clamp [7] ,[8], [9] can be used to reduce voltage spikes on the power switches. Although an RCD snubber protects the switch, it reduces the converter efficiency. Active clamp circuits increase the efficiency of the converter by using extra switches and components. A voltage clamp circuit consists of a diode and a capacitor or integrated converters such as a boost-fly back and a boost-sepic. This helps the leakage inductance energy to discharge without an extra switch or another component. So, the switch voltage level can be reduced.

The voltage gain can be increased by using switched inductor [10], [11], switched capacitor [12], [13], voltage lift or voltage multiplier cell techniques. These converters need cascade connections to attain higher voltage ratios. But, this causes complexity and lower efficiency. High voltage gain can be obtained by employing a coupled inductor in nonisolated for high-efficiency systems, energy stored in the leakage inductance should not increase the voltage stresses of switches and diodes.

\section{System Description}

\subsection{Methodology}

Fig. 3.1 shows the modified converter. There is one coupled inductor with four windings in the proposed converter. For the ease of understanding, it is shown in the figure as if there are two cores, $T_{1}$ and $T_{2}$. However, in real circuit, all coils are wound on the same core. Each coupled inductor has two windings. Turns ratios of these windings are $\mathrm{N}_{1}$ and $\mathrm{N}_{2}$. Primary and secondary inductances of the coupled inductors are $\mathrm{L}_{1}$ and $\mathrm{L}_{2}$. The detailed representation of the modified converter is shown in Fig.3.2. The equivalent model of the coupled inductors includes the magnetizing inductors $\mathrm{L}_{\mathrm{m}}$, the primary leakage inductor $\mathrm{L}_{\mathrm{lk} 1}$, the summation secondary leakage inductor $\mathrm{L}_{\mathrm{lk} 2}$.

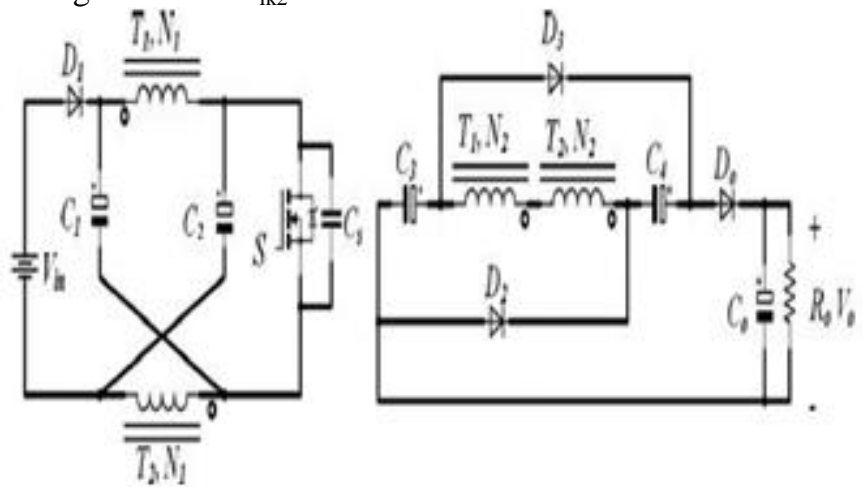

Figure 3.1: Circuit diagram

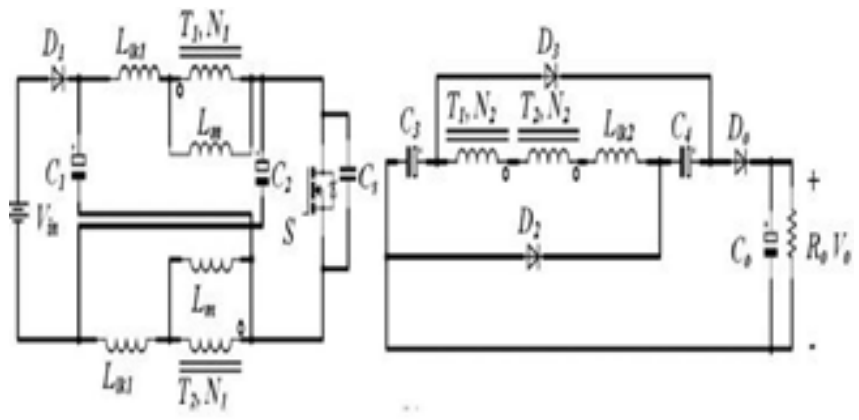

Figure 3.2: Equivalent Circuit

\section{Volume 4 Issue 11, November 2015}




\section{International Journal of Science and Research (IJSR) \\ ISSN (Online): 2319-7064}

Index Copernicus Value (2013): 6.14 | Impact Factor (2014): 5.611

\subsection{Basic operating principle}

Before taking up this section, there are some assumptions to be made

1) The turn ratio of the coupled inductor is low

2)The leakage inductance energy does not create stress on the switches or diodes

3) Switch voltage rating is low

4)Isolation exists between input and output

The circuit also employs five capacitors $\left(\mathrm{C}_{0}, \mathrm{C}_{1}, \mathrm{C}_{2}, \mathrm{C}_{3}\right.$ and $\left.C_{4}\right)$, four diodes $\left(D_{0}, D_{1}, D_{2}\right.$ and $\left.D_{3}\right)$, and a power switch $(S)$. When the power switch is turned $\mathrm{ON}$, the diodes $\mathrm{D}_{1}, \mathrm{D}_{2}$ and $\mathrm{D}_{3}$ are OFF while the diode Do conducts. The capacitors $\mathrm{C}_{1}$, $\mathrm{C}_{2}, \mathrm{C}_{3}$ and $\mathrm{C}_{4}$ are discharged, while the load capacitor Co is charged. When the power switch is turned OFF, the diodes $\mathrm{D}_{1}, \mathrm{D}_{2}$ and $\mathrm{D}_{3}$ starts conducting and the diode $\mathrm{D}_{0}$ is OFF. The capacitors $C_{1}, C_{2}, C_{3}$ and $C_{4}$ are charged. The capacitor $C o$ is discharged. While the primary leakage inductance energy is discharged through the capacitors $\mathrm{C}_{1}, \mathrm{C}_{2}$ and the diode $\mathrm{D}_{1}$, the secondary leakage inductance energy is discharged through the load. In the meantime, the switch and the diodes do not experience extra stress.

\subsection{Modes of Operation}

Each switching period can be divided into seven subintervals. The operating modes are described as follows:

\subsubsection{Mode1}

The switch is conducting in this mode. It is assumed that the stray capacitor $C_{s}$ quickly discharges. The diodes $D_{o}$ and $D_{1}$ are $\mathrm{OFF}$ while the diodes $\mathrm{D}_{2}$ and $\mathrm{D}_{3}$ conduct the cur-rent.The capacitors $\mathrm{C}_{1}$ and $\mathrm{C}_{2}$ are discharged. The magnetizing and leakage inductors $\mathrm{L}_{\mathrm{m}}$ and $\mathrm{L}_{\mathrm{k} 1}$ are charged by $\mathrm{V}_{\mathrm{c}}$ voltage. The leakage inductor $\mathrm{L}_{\mathrm{lk} 2}$ discharges its energy through parallel the capacitors $C_{3}$ and $C_{4}$. The secondary current $i_{12}$ linearly decays, causing soft recovery of diodes. The capacitor $\mathrm{C}_{\mathrm{o}}$ is discharged through the load. This mode ends when $\mathrm{i}_{\mathrm{D} 2}=\mathrm{i}_{\mathrm{D} 3}=$ 0

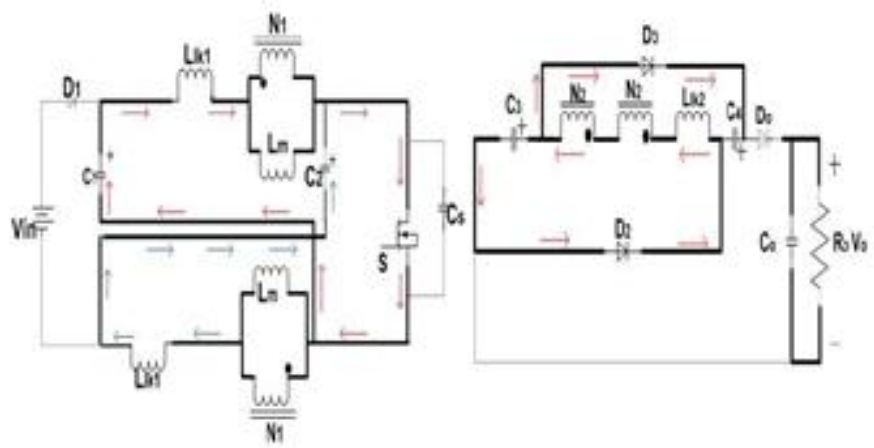

Figure 3.3.1: Mode 1

\subsubsection{Mode 2}

This is also a short mode. The switch is still conducting. The diode $\mathrm{D}_{0}$ conducts while the diodes $\mathrm{D}_{1}, \mathrm{D}_{2}, \mathrm{D}_{3}$ are OFF. The capacitors $\mathrm{C}_{1}$ and $\mathrm{C}_{2}$ and the inductors $\mathrm{L}_{\mathrm{m}}$ and $\mathrm{L}_{\mathrm{kk} 1}$ keep their states as in Mode $\mathrm{I}$. The capacitors $\mathrm{C}_{3}$ and $\mathrm{C}_{4}$ are in series and discharged through the load. The capacitor $\mathrm{C}_{0}$ is charged.

This mode ends when $\mathrm{v}_{\mathrm{L} 2}=\mathrm{n} \mathrm{v}_{\mathrm{L} 1}$

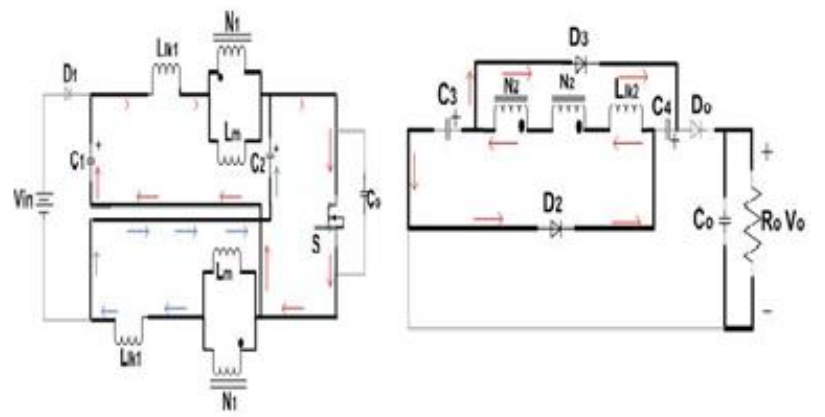

Figure 3.3.2: Mode 2

\subsubsection{Mode 3}

In this mode, the switch, diodes, capacitors, and inductors keep their states as in Mode I. The magnetizing inductor Lm transfers the stored energy to the secondary. The secondary side of the coupled inductors is in series with the capacitors $\mathrm{C}_{3}$ and $\mathrm{C}_{4}$ by charging them to a voltage level depending on the conversion ratio and passes the energy to the load. This mode ends when the switch is turned OFF.
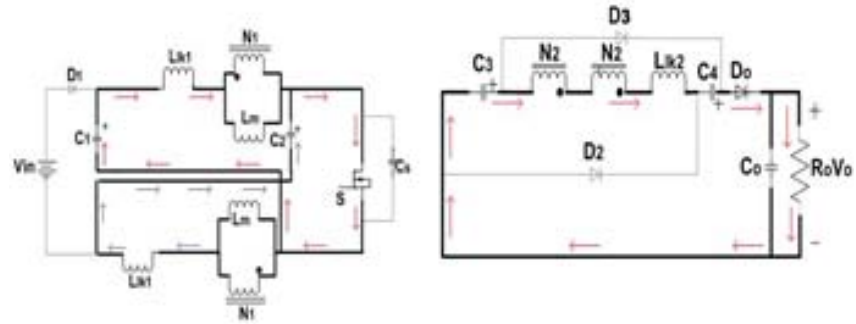

Figure 3.3.3: Mode 3

\subsubsection{Mode 4}

This is also a short mode. When the switch is turned OFF, the stray capacitor Cs starts to charge quickly. The diodes, capacitors, and inductors keep their states as in Mode III. This mode ends when the diode $\mathrm{D}_{1}$ starts conducting.



Figure 3.3.4: Mode 4

\subsubsection{Mode 5}

This is also a short mode. The switch and the diodes $\mathrm{D}_{2}$ and $\mathrm{D}_{3}$ are OFF while the diodes Do and D1 conduct the current. The energy stored in $\mathrm{Lm}$ and $\mathrm{L}_{\mathrm{lk} 1}$ is discharged throughC $\mathrm{C}_{1}, \mathrm{C}_{2}$ capacitors and the source. The leakage inductor $\mathrm{L}_{\mathrm{lk} 2}$ discharges its energy through the series capacitors $\mathrm{C} 3$ and $\mathrm{C}_{4}$ and the load. The capacitor Co is charged. This mode ends when diode $\mathrm{D}_{0}$ is OFF 


\section{International Journal of Science and Research (IJSR) \\ ISSN (Online): 2319-7064}

Index Copernicus Value (2013): 6.14 | Impact Factor (2014): 5.611

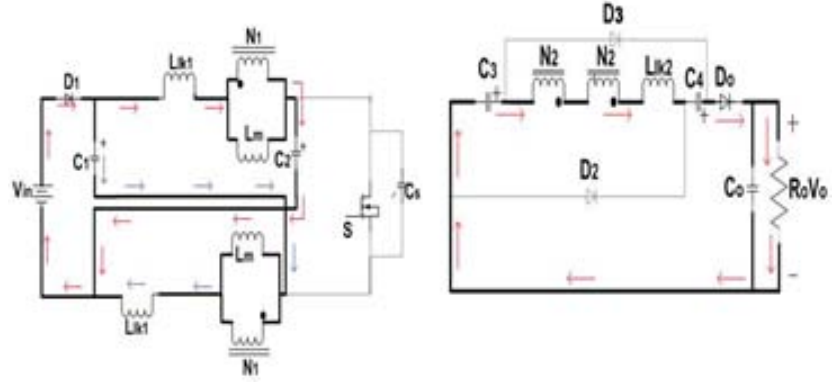

Figure 3.3.5: Mode 5

\subsubsection{Mode 6}

This is also a short mode. The switch and diode $\mathrm{D}_{0}$ are OFF while the diodes $\mathrm{D}_{1}, \mathrm{D}_{2}$ and $\mathrm{D}_{3}$ conduct the current. In this mode, the energy stored in $\mathrm{L}_{\mathrm{m}}$ and $\mathrm{L}_{\mathrm{lk} 1}$ is still discharged through the capacitors $\mathrm{C}_{1}$ and $\mathrm{C}_{2}$ and the source. The capacitors $\mathrm{C}_{1}, \mathrm{C}_{2}, \mathrm{C}_{3}$ and $\mathrm{C}_{4}$ are charged. The load capacitor $\mathrm{C}_{0}$ is discharged through the load. This mode ends when $\mathrm{vL} 2=\mathrm{n} v \mathrm{~L} 1$.
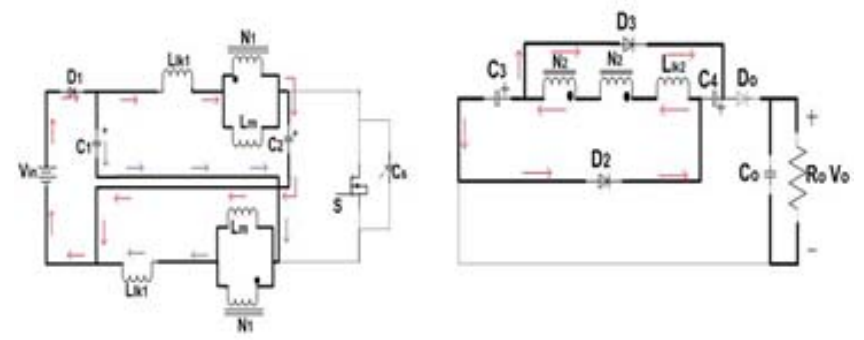

Figure 3.3.6: Mode 6

\subsubsection{Mode 7}

In this mode, the switch and diodes keep their states as in Mode VI. In this mode, the stored energy in $\mathrm{Lm}$ is transferred to the secondary side. The capacitors $\mathrm{C} 1$ and $\mathrm{C}_{2}$ are still charged. The secondary of the coupled inductors is in parallel to the capacitors $\mathrm{C}_{3}$ and $\mathrm{C}_{4}$, and charges them to a voltage level depending on the conversion ratio. The load capacitor $\mathrm{C}_{0}$ is still discharged through the load. This mode ends when the switch is turned $\mathrm{ON}$.


Figure 3.3.7: Mode 7

\subsection{Design Considerations}

\subsubsection{Duty-Cycle Ratio and Turns Ratio}

The turns ratio $\mathrm{n}$ and the duty cycle ratio $\mathrm{D}$ can be selected as 2.9 and 0.28 , respectively. The desired nominal voltage gain value is 16 for output voltage $400 \mathrm{~V}$ and input voltage $25 \mathrm{~V}$. The operation region of the converter is limited to duty cycle ratio less than 0.5 .

\subsubsection{Selection of Capacitors}

The average voltage of the coupled inductor and the average current of the capacitors $\mathrm{C}_{1}, \mathrm{C}_{2}, \mathrm{C}_{3}, \mathrm{C} 4$ and $\mathrm{C}_{\mathrm{o}}$ are zero at steady state. The currents of the capacitors $\mathrm{C}_{1}$ and $\mathrm{C}_{2}$ and the capacitors $\mathrm{C}_{3}$ and $\mathrm{C}_{4}$ are same.

$\mathrm{C}=\mathrm{I}_{\mathrm{C}} \Delta \mathrm{T} / \Delta \mathrm{V}(3.1)$

\subsubsection{Coupled Inductor}

The primary inductance of coupled inductor is

$$
\mathrm{L}_{1}=\mathrm{V}_{\mathrm{Cl}} \mathrm{DT}_{\mathrm{S}} / \Delta \mathrm{I}(3.2)
$$

The secondary inductance of coupled inductor is

$$
\mathrm{L}_{2}=\mathrm{L}_{1}\left[\mathrm{~N}_{2} / \mathrm{N}_{1}\right]^{2}(3.3)
$$

\section{Isolated Converteencorporatig PV with MPPT}

\subsection{Maximum Power Point Tracking}

Maximum Power Point Tracking, frequently referred to as MPPT, is an electronic system that operates the Photovoltaic (PV) modules in a manner that allows the modules to produce all the power they are capable of. MPPT is not a mechanical tracking system that physically moves the modules to make them point more directly at the sun. MPPT is a fully electronic system that varies the electrical operating point of the modules so that the modules are able to deliver maximum available power. Additional power harvested from the modules is then made available as increased battery charge current. MPPT can be used in conjunction with a mechanical tracking system, but the two systems are completely different.

In incremental conductance method the array terminal voltage is always adjusted according to the MPP voltage it is based on the incremental and instantaneous conductance of the PV module. Fig 4.1 shows that the slope of the P-V array power curve is zero at the MPP, increasing on the left of the MPP and decreasing on the right hand side of the MPP. When the ratio of change in output conductance is equal to the negative output conductance, the solar array will operate at the maximum power point. This method exploits the assumption of the ratio of change in output conductance is equal to the negative output Conductance Instantaneous conductance.

In incremental conductance algorithm first we check whether change in voltage is zero. If yes check whether change in current is zero. If no decrease operating voltage. Otherwise increase the operating voltage. If incremental conductance condition is not satisfied, check whether the incremental conductance is greater than ratio of change in cur-rent to voltage. If yes increase the operating voltage. Otherwise decrease operating voltage. 


\section{International Journal of Science and Research (IJSR) \\ ISSN (Online): 2319-7064}

Index Copernicus Value (2013): 6.14 | Impact Factor (2014): 5.611

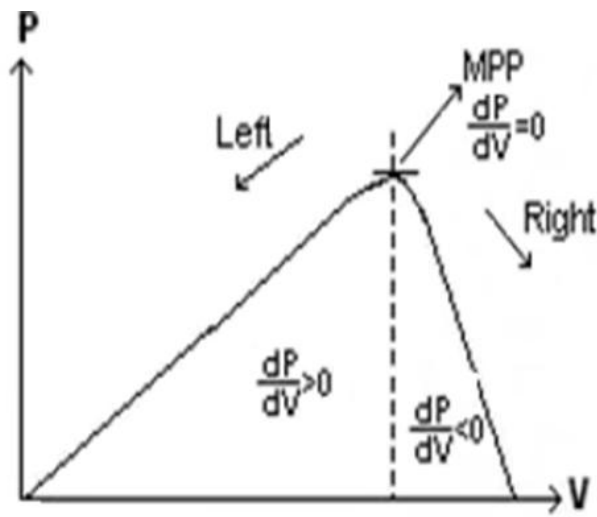

Figure 4.1: Incremental Conductance MPPT

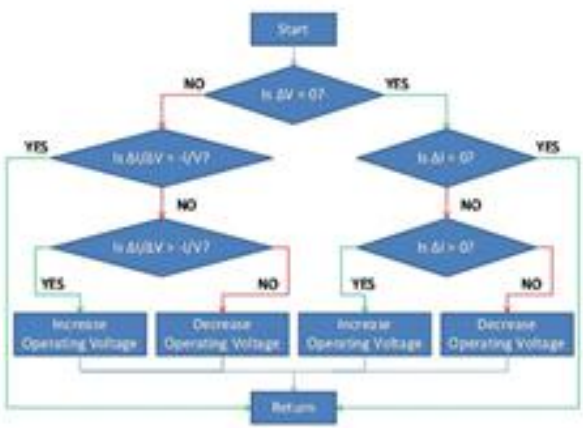

Figure 4.2: Incremental Conductance MPPT Algorithm

There is another algorithm used by MPPT .It is Perturb and observe algorithm. The module voltage is periodically given a perturbation and corresponding output power is compared with that of the previous perturbing cycle. A slight perturbation is introduced to the system. This perturbation causes power of solar module various. If power increases due to perturbation then perturbation is continued in same direction. After peak power is reached power at MPP is zero and next instant decreases and hence after that perturbation reverses. On left of MPP incrementing voltage increases power whereas on right decrementing voltage increases power. On left of MPP incrementing voltage increases power whereas on right decrementing voltage increases power. If there is increment in power, the perturbation should be kept in the same direction and if power decreases the next perturbation should be in the opposite direction.

\section{Simulation Result}

A PV cell is basically a PN junction and acts as a current source. Energy from sunlight is directly converted in to electrical energy. Where the photons are absorbed by the semiconductor and free electrons are released. The generated voltage of $\mathrm{PV}$ is low and typically lies around $0.5 \mathrm{~V}$ and $0.8 \mathrm{~V}$ which depends on the semiconductor used.

Here the solar cell is modeled and the output from PV is about 22.2 V. The output of PV panel is shown in fig 5.2.By means of MPPT we were able to track maximum power. The $\mathrm{P}-\mathrm{V}$ curve is shown in fig 5.4..MPPT finds out array current and voltage every-time to determine proper direction to move the operating point. Eventually this completely updated set point will fluctuate around voltage corresponding to array peak power point. By adjusting operating point of array to peak power output, the output power is maximized and efficient use of solar array may be realised.The output voltage of the converter is boosted up. The output voltage of the converter is shown in $\mathrm{g} 5.3$

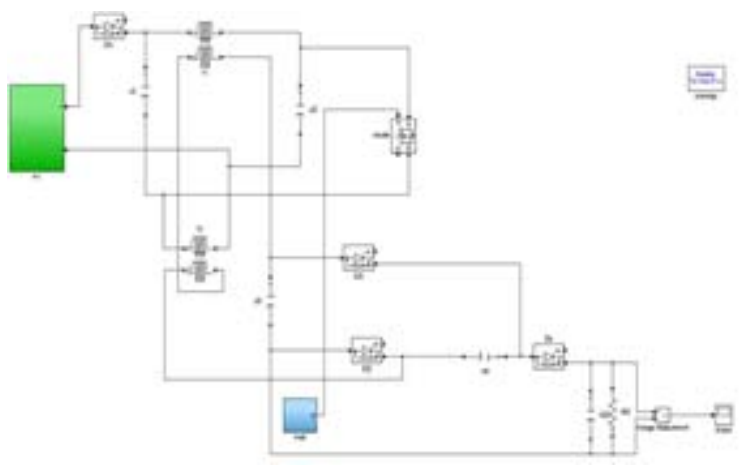

Figure 5.1: Main Circuit Topology

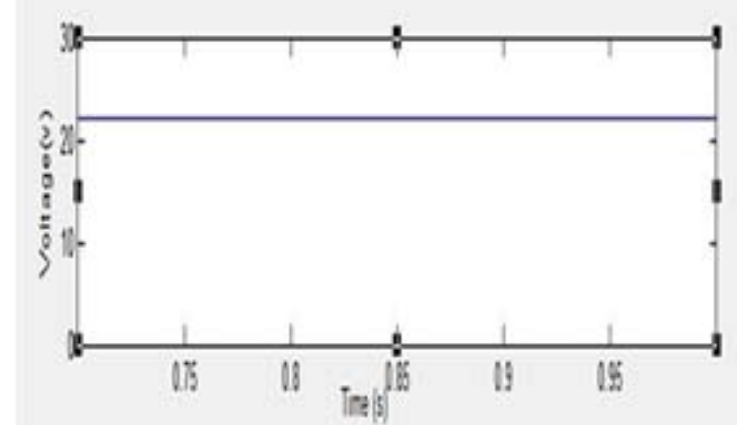

Figure 5.2: Output of PV panel

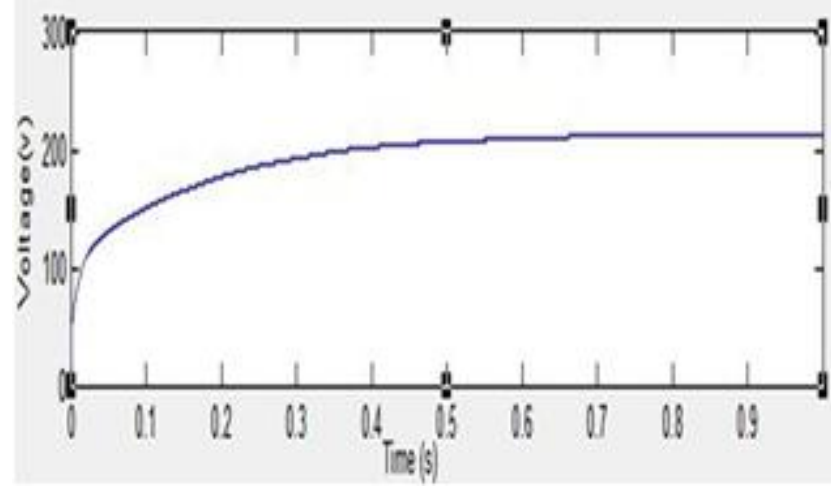

Figure 5.3: Output voltage of converter

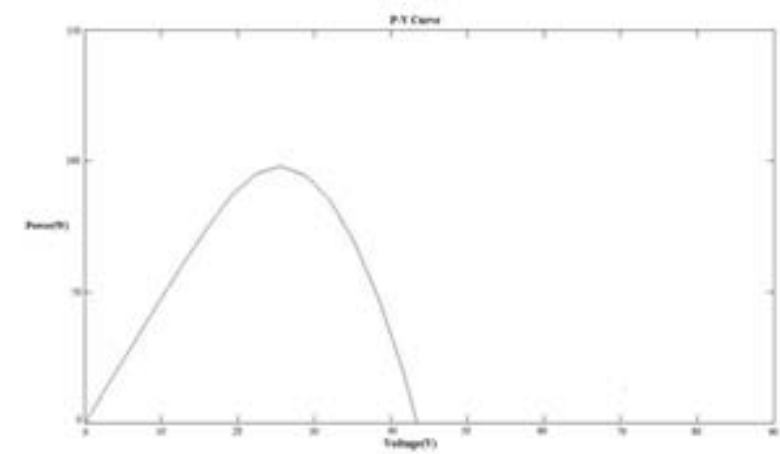

Figure 5.4: PV Curve

\section{Hardware Setup of Converter Encorporating PV}

A hardware model of the high gain dc-dc converter was 


\section{International Journal of Science and Research (IJSR) \\ ISSN (Online): 2319-7064}

Index Copernicus Value (2013): 6.14 | Impact Factor (2014): 5.611

developed.Here we use coupled inductor.The primary turns of coupled inductor is 16 turns and the secondary turns is 46 turns.

\subsection{System Model}



Figure 6.1.1: Block Diagram

From power distribution across large distances to radio transmissions, coupled induc- tors are used extensively in electrical applications. Their properties allow for increasing or decreasing voltage and current, transferring impedance through a circuit, and they can isolate two circuits from each other electrically. There are a wide variety of applications which exploit properties of transformers, such as tesla coils, impedance matching in audio frequency applications, potential transformers for reading very high voltages, Scott-T trans-formers which convert twophase components to threephase (or vice versa), and many more.

The output voltage of PV is $12 \mathrm{~V}$.The switch-ing frequency is 50KHz.IRFP250 is used as the mosfet.The optocoupler used is TLP250.

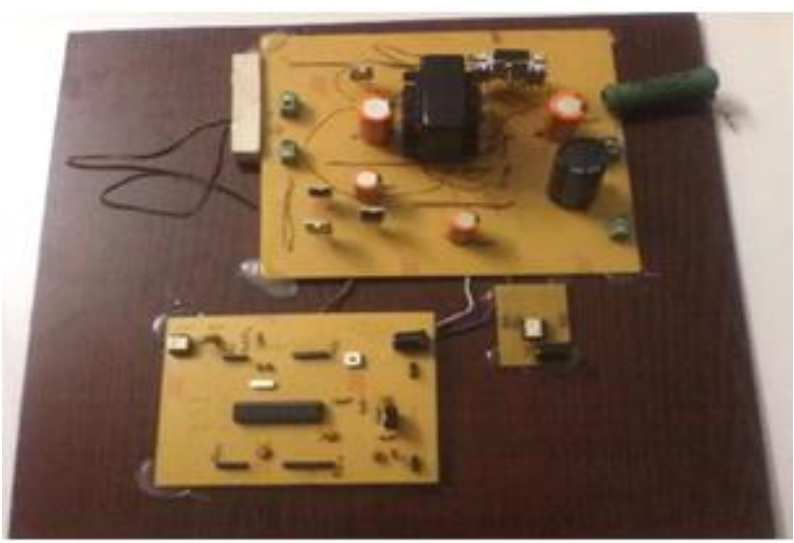

Figure 6.1.2: Hardware setup

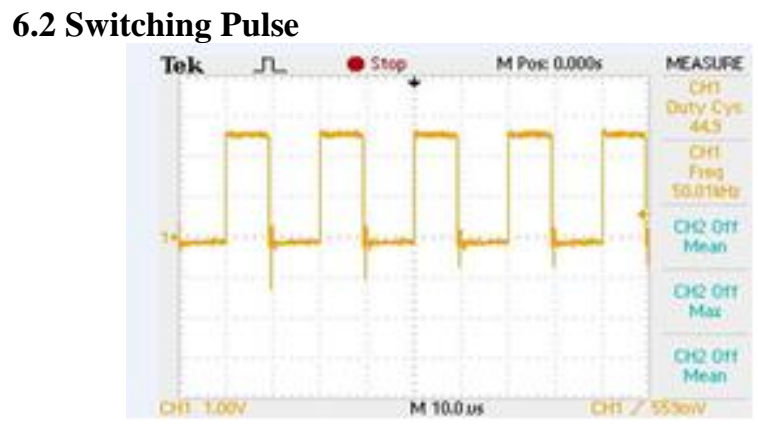

\subsection{Output of PV and Converter}

Figure 6.2.1: Switching Pulse

The output voltage and current of PV is shown in figure 6.3.1 and the output of converter is shown in $\mathrm{g}$ 6.3.2.
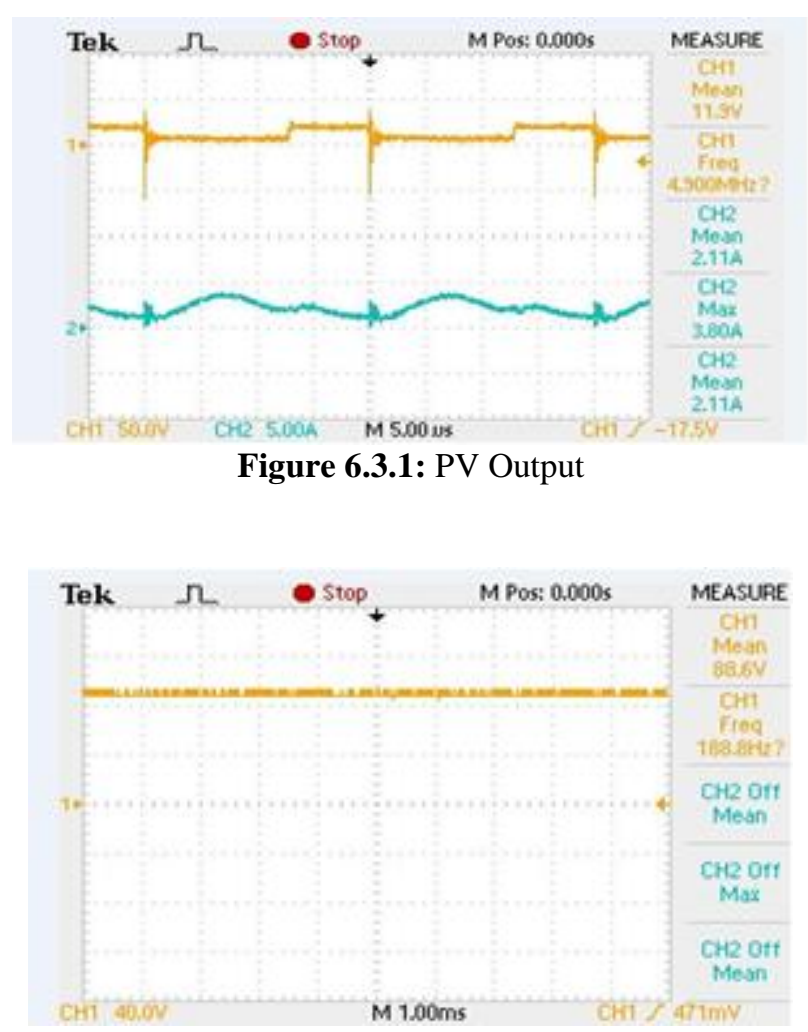

Figure 6.3.2: Converter Output

\section{Conclusion}

An isolated high step-up dc-dc converter with low voltage stress is presented. The proposed converter achieves extremely large voltage conversion ratio with appropriate duty cycle and reduction of voltage stress on the power devices. The topology utilizes coupled inductor. The leakage inductance energy can efficiently be discharged. Since the device stresses are low in this topology, low voltage MOSFETs with small $\mathrm{R}_{\mathrm{DS}}($ on) values can be selected to reduce the conduction loss. These features improve the converter efficiency. When com-pared to other topologies the proposed converter contain only one switch which simplify the circuit configuration and improve the system reliability. All these factors improve the circuit performance in the high step-up applications. Isolated DC-DC boost converter sourced by a PV panel was simulated by MPPT algorithm. The $\mathrm{P}$ and $\mathrm{O}$ algorithm implemented was found successful in tracking the maximum power from the PV panel. The switching losses will be less when compared to conventional topologies since less number of power electronic switches are used .

\section{References}

[1] S. B. Kjaer, J. K. Pedersen, and F. Blaabjerg, \A review of single-phase grid-connected inverters for photovoltaic modules,"IEEE Trans. Ind. Appl., vol. 41, no. 5, pp. 1292-1306, Sep./Oct. 2005.

[2] R.-J.Wai, C.-Y. Lin, R.-Y. Duan, andY.-R. Chang, High-efficiency power conversion system for kilowattlevel stand-alone generation unit with low input voltage," IEEE Trans. Ind. Electron., vol. 55, no. 10, pp. 3702-3714,Oct. 2008. 
[3] S. J. Finney, B. W. Williams, and T. C. Green, $\mathrm{IRCD}$ snubber revisited," IEEE Trans. Ind. Appl., vol. 32, no. 1, pp. 155-160, Jan/Feb. 1996..

[4] W.-Y. Choi and J.-Y. Choi, UHigh-efficiency power conditioning system for grid-connected photovoltaic modules," J. Power Electron., vol. 11, no. 4, pp. 561567, Sep. 2011.

[5] G. Spiazzi, P. Mattavelli, and A. Costabeber, \High stepup ratio yback converter with active clamp and voltage multiplier," IEEE Trans. Power Electron., vol. 26, no. 11, pp. 3205-3214, Nov. 2011.

[6] C.-W. Roh, C.-H. Yoo, D.-Y. Jung, and S.-C. Sakong, Polarity inversion DCDC power conversion circuit with high voltage step-up ratio," J. Power Electron., vol. 11, no. 5, pp. 669-676, 2011.

[7] G. M. L. Chu, D. D. C. Lu, and V. G. Agelidis, FFly back-based high stepup converter with reduced power processing stages," IET Power Electron., vol. 5, no. 3, pp. 349-357, Mar. 2012.

[8] Y. Zhao,W. Li, and X. He, ISingle-phase improved active clamp coupled inductor- based converter with extended voltage doubler cell," IEEE Trans. Power Electron., vol. 27, no. 6, pp. 2869-2878, Jun. 2012..

[9] S. Jiang, D. Cao, Y. Li, and F.-Z. Peng, IGrid-connected boost-half-bridge photovoltaic micro inverter system using repetitive current control and maximum power point tracking," IEEE Trans. Power Electron., vol. 27, no. 11, pp. 4711-4722, Nov. 2012.

[10] Y. Jiao, F. L. Luo, and M. Zhu, IVoltage-lift-type switched-inductor cells for enhancing DCDC boost ability: Principles and integrations in Luo converter," IET Power Electron., vol. 4, no. 1, pp. 131-142, Jan. 2011.

[11] K. I. Hwu and Y. T. Yau, LHigh step-up converter based on charge pump and boost converter," IEEE Trans. Power Electron., vol. 27, no. 5, pp. 2484-2494, May 2012

[12]C.-K. Cheung, S.-C. Tan, C. K. Tse, and A. Ioinovici, IOn energy e ciency of switched-capacitor converters," IEEE Trans. Power Electron., vol. 28, no. 2, pp. 862876, Feb. 2013.

[13] W. Qian, D. Cao, J. G. Cintron-Rivera, M. Gebben, D. Wey, and P. Fang Zheng, $\backslash$ A switched-capacitor DCDC converter with high voltage gain and reduced component rating and count," IEEE Trans. Ind. Appl., vol. 48, no. 4, pp. 1397-1406, Jul./Aug. 2012. controllers,” Rev. Fac. Ing. Univ. Antioquia N. ${ }^{\circ} 66$ pp. 118-130. Marzo, 2013.

\section{Author Profile}

Parvathi Mohan was born in Kerala, India. She received the B.Tech. Degree in electrical engineering from kerala University, Kerala, India , in 2012, and She is currently pursuing her M.Tech in Power Electronics \& Power Systems Federal institute Of Science \& Technology ,Angamali,Kerala, India.

Sreeja Miss was born in Kerala, India. She received the B.Tech. degree in electrical engineering from GEC Thrissur, Kerala, India, in 1997, and the M. Tech degree in Power Electronics from School of Engineering Cusat. She currently works as assistant professor at Fisat College of engineering, Angamaly. 